\title{
Formation of Export Potential of Regional Economy
}

\author{
Zoya A. Vasilyeva 1[ORCID 0000-0002-8899-5262], \\ Irina V. Filimonenko ${ }^{1 *[O R C I D}$ 0000-0003-1237-5478], \\ Tatiana P. Likhacheva 1[ORCID 0000-0001-6814-0438]
}

\author{
${ }^{1}$ Siberian Federal University, Krasnoyarsk, Russia \\ ifilimonenko@sfu-kras.ru
}

\begin{abstract}
Change in the structure of global commodity markets' demand for high-tech science-intensive digital technologies influence the existing structure of economies of raw material regions and form new requirements for the product portfolio of exports. One of the main trends of export regional potential is becoming the expansion of assortment due to high-tech products with a high share of added value in the economy of a region. However, the existing methodological approaches to the assessment of external demand of a region are not focused on achieving structural transformations of regional economy; the existing mechanisms of state support are mainly aimed at the interests of local businesses in the short-term period of development. The purpose of the article is to propose methods for the formation of export potential of regional economy on the basis of development of high-tech fields, new sectors and markets. A system-structure approach to research, which was developed by the authors, includes clarifying the concept of export potential, identifying the stages of its formation and development, determining the performance metrics of choosing marketable products to form a regional export potential, highlighting the direction of the development of the latter. Based on the comparative analysis of approaches to the assessment and development of a regional export potential, the authors formulated a basic premise to model its structure and level assessment: the requirement to distinguish between ways of revealing and assessing priority and long-range types of export products. A step-by-step methodology to form a regional export potential, which is aimed at selecting both priority types of existing export products and new types of promising high-tech products for the growth in regional exports on the global market, is proposed. As methods for selecting priority types of export products the authors used a structural dynamic analysis, a grouping method based on the XYZ-analysis and variation coefficients, a positioning method. To substantiate the choice of new types of promising products for the growth in regional exports on the global market, the following methods were used: intersection of sets, evaluation of the potential of global commodity markets and of a potential share of commodity position in regional exports, evaluation of comparative advantage of countries based on the Balassa index. Approbation of methods for forming a regional export potential is presented using the example of the Krasnoyarsk Territory.
\end{abstract}

Keywords: export commodity structure, export potential, global market, manufacturing and technological chains, regional economy, structural modernization of economy

\section{INTRODUCTION}

One of the most important tasks of economic development of Russia is the expansion of nonresource exports [1]. At present, the growth of Russian economy is predominantly determined by resources with low added value. The change in commodity structure of exports due to an increase in the share of products with high added value is an objective necessity as structural repositioning in global production and technological chains allows regions to obtain the opportunity of long-term economic growth, to be not only suppliers of resources on the global market, but also leaders that control the development of new markets of high-tech products and form the access to mass markets of final demand products with a high consumer potential. So, the set task to expand regional nonresource exports is transformed into the task to form and develop an export potential by producing and 
globally marketing competitive high-tech products.

However, the analysis of scientific publications on issues of formation and development of regional export potential allowed us to reveal certain scientific and methodological problems. Firstly, the existing methodological approaches to the formation of regional export potential are mainly oriented to the study of the structure of exports and the factor influence on large-scale indicators of exports (volumes, sale prices, profitability of export supplies, etc.) without assessing their effect on structural transformations of regional economy [27]. Secondly, the absence of scientifically grounded choice for high-tech products to develop export potential creates the uncertainty while determining the strategic directions of state support for regional exporters. Thirdly, the generally accepted approaches to identifying the export potential as a set of regional resources for the production and sale of products in foreign markets (e.g., [2-5]) or as capabilities of resources to maximize the volumes of product exports in the future [6] do not allow disclosing possibilities of export potential to ensure the economic growth of a region.

In this regard, the methodology for the formation of a list of priority types of high-tech products of regional manufacturers, in order to develop the export potential of a region and meet the external demand, should consider the prospects for expanding value chains; the possibility to enter the world commodity markets; the ability to form new high-tech product markets, including the global ones; the possibility of high-tech products to effect on changes in the sectoral structure of the economy of a region to ensure sustainable economic growth.

\section{MATERIALS AND METHODS}

The purpose of the article is to propose methods for forming the export potential of the economy of a region on the basis of the development of high-tech industries, high-tech businesses, new sectors, which allow increasing the added value of products due to the new quality of manufacturing and technological processes (rate, accuracy, flexibility, complexity) and forming new markets of high-tech products.

To achieve the set purpose, the authors developed a system-structure approach to the study. Stages of the study include the clarification of the concept of export potential due to the appearance of new characteristic features in the conditions of innovative and technological development of economy; the identification of phases of the formation and development of export potential; the substantiation of economic indicators which evaluate the performance and effectiveness of export potential; the determination of directions for the development of regional export potential.

The initial data of the proposed methodology are customs statistics of foreign trade and statistics of the economic development of the region [8-10].

\section{RESULTS}

The traditional analysis of scientific publications showed that most frequently, export growth potential of regional economy implied the possibility to sell regional products in global markets. From our point of view, the formation of export potential of the region as a key long-term factor in the growth of the economy of the region is determined by the ability to create high-tech products with a high share of added value, the availability of intellectual resources and digital technologies. In accordance with the goals of this study, the authors understand the export potential of the region as the provision of the regional economic system with intellectual resources, technologies for manufacturing high-tech products (goods and services with a high share of added value, digital technologies of promotion to the world markets, in order to meet foreign effectual demand and ensure the regional economic growth) [11].

The comparative analysis of studies in the field of assessing and developing the export potential of the region [12-16] allowed us to formulate the basic premise of modeling its structure and level assessment: the need to distinguish between methods of identifying and assessing priority and promising types of export products. Despite the fact that the national technological trend is determined by the development of high-tech industries, one should take into account the diversity of the economy of the regions of Russia. The high-tech sector with export potential occupies only an insignificant share in the structure of the economy. Therefore, the structural and technological modernization of the economy cannot be carried out exclusively by creating hightech industries. At present, the demand for nonprimary export products (mineral, metallurgical, chemical, of plant and animal origin, etc.) has sharply increased on the world markets. In our opinion, the priority types of products for the export potential include the existing types of export products of the region, provided by large-scale and stable demand on the world commodity and service markets. The promising types include new types of 
high-tech products that correspond to the strategic development priorities of importing countries and are in the top positions of world exports $[17,18]$.

When determining the range of high-tech products for the export potential of the region, we proceed from the need to achieve the following development benchmarks in the regional economy in the short and medium term $[19,20]$ :

- differentiation of priority export products in the world commodity markets on the basis of comparative (competitive) advantages (consumer properties, delivery speed, adaptation to specific needs, etc.);

- technological independence of the region from external suppliers on the basis of the introduction of modern high-tech industries at all stages of production process chain;

- strategic repositioning of regional manufacturers in global markets of goods and services due to the concentration of the production of priority high-tech products mostly secured by effective demand in global markets, as well as to the expansion of the production of promising high-tech products of top positions of world exports (new technologies of materials, new technologies of production).

To substantiate the methods for identifying and assessing export products, a methodology was used that includes four stages. The first two stages are intended to select priority products for export expansion. The next two are for the selection of promising products for the growth of regional exports in global markets.

1) Identification of existing volumes and structure of external effective demand on the basis of an assessment of factual scales of regional exports, and stable trends in the external demand development to determine the stages of life cycle of regional products. This allows determining differentiated groups and types of priority export products with a stable and highest potential of effective demand.

Research methods for the first stage are a structural dynamic analysis of volumes of regional exports for the last five years, XYZ-analysis, taking into account the dynamics and the level of demand fluctuations for specific types and groups of export products, grouping method. Indicators characterizing scales of exports and effective demand for product groups are volumes and dynamics of exports; structure by groups and types of products; scales of demand for groups of export products; coefficient of demand variation. Criteria for quantifying the levels of demand of importing countries for products of regional exports are levels of scales, sustainability and stages of life cycle of the demand for product groups and types.

Although the performed groupings are very important, there is a need to assess the combined effect of these factors on the dependence of importing countries on regional product exports, identifying types of products, the priority of which is determined by stable and effective positioning in global commodity markets.

2) Assessment of the priority of regional export products in terms of the possibility of retaining or increasing volumes of exports due to the expansion of external effective demand both from manufacturing enterprises and households [21-22].

Research methods are positioning and grouping of types of export products in the coordinates of the "demand scale level - demand dynamics level" matrix; analysis of the structure of exports by importing countries. Indicators of the analysis are scales and dynamics of growth rate of effective demand for export product groups and types. Criteria for quantifying the volumes of critical demand for groups and types of export products are the position of an export group in the coordinates of the "demand scale level - demand dynamics level" matrix; the share of exports with a high risk to determine quantitative parameters of demand for promising types of marketable products.

It is proposed to assess the priority of types of marketable products to expand regional exports on the basis of their positioning in the "demand scale level - demand dynamics level" matrix. The result is the ability to select priorities based on a crossclassification of the scale and dynamics of demand for specific groups and types of products (Figure 1). The matrix contains 4 standard positions for commercial products that differ in the size and dynamics of demand of industrial enterprises. In addition, the positioning of products in the quadrants of the matrix makes it possible to justify the choice of various forms of export expansion and the direction of industrial cooperation. 


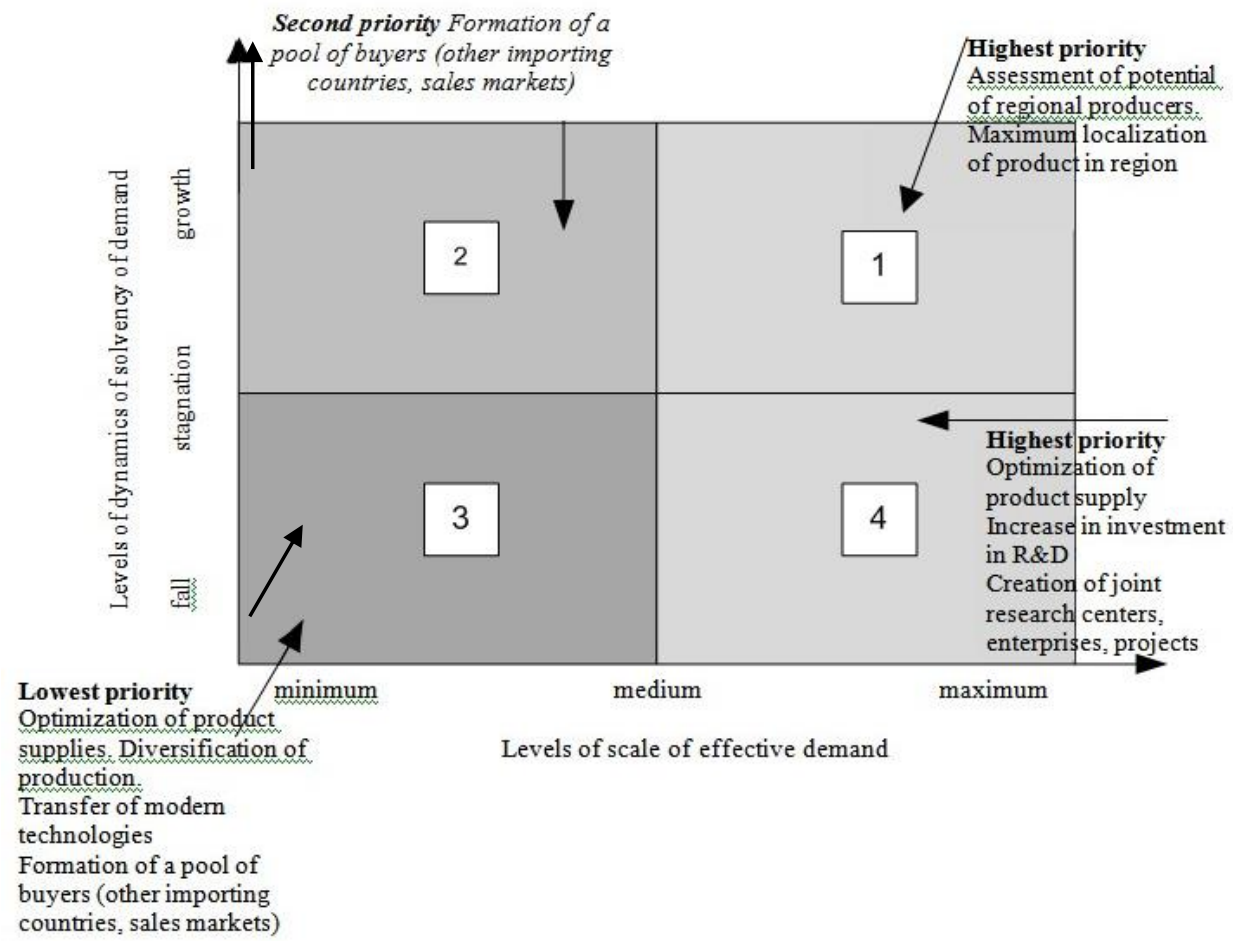

Figure 1. Matrix of positioning of export products in coordinates of levels of scale of effective demand - levels of dynamics of effective demand

Source: Compiled by the authors

Possible positions for the selection of priority products for export expansion are:

- quadrant 1 highest priority for export expansion: product groups with a maximum level of demand or an above average level on the part of importing countries and high rates of its growth (stages of demand development are active growth, growth); effective forms of export expansion are the maximum possible localization of products in the region based on an assessment of the export potential of regional producers;

- quadrant 2 second priority for export expansion: product groups with small volumes of demand (demand levels are minimal and below average), but high rates of its increase; effective forms of export expansion are formation of a pool of consumers from other importing countries and sales markets;

- quadrant 3 lowest priority for export expansion: product groups with small volumes of demand (demand levels are minimal and below average) and possibly insignificant rates of its change, or a tendency to decrease in demand; effective forms of export expansion can be optimization of product supplies, diversification of production, transfer of modern technologies, strategies for innovative development;

- quadrant 4 highest priority for export expansion: product groups with a maximum demand level or an above average demand level on the part of the industrial complex of the region and with insignificant rates of its growth (stages of demand development are stagnation, fall) should also be attributed to the highest priority due to the high levels of dependence of importing countries on the region's exports; effective forms of export expansion are optimization of product supplies, increase in investment in $R \& D$, the creation of joint research centers, enterprises, projects [11, 23]

3) Identification of promising export products of the region on the basis of establishing a correspondence between each new commodity item of high-tech exports of the region and commodity groups from the list of the world's top imports [16]. An example of the correspondence of commodity items when comparing TOP-20 'Export of the Krasnoyarsk Territory' and 'Top-world Export' in 2019 is presented in Table 1 [24-26]. 
Table 1. Correspondence table of positions in the pair 'Top-world Import' - 'Top-export of the Krasnoyarsk Territory' in 2019 (fragment)

\begin{tabular}{|c|c|c|c|c|c|}
\hline \multicolumn{2}{|c|}{ Commodity Group } & \multirow{2}{*}{$\begin{array}{c}\text { Import } \\
\text { Volumes in } \\
2019 \\
\$ \text { billion }\end{array}$} & \multirow{2}{*}{$\begin{array}{c}\text { Correspondence } \\
\text { of Commodity } \\
\text { Groups }\end{array}$} & \multirow[b]{2}{*}{$\begin{array}{l}\text { Region Export } \\
\text { Commodity Group }\end{array}$} & \multirow{2}{*}{$\begin{array}{c}\text { Export } \\
\text { Volumes in } \\
2019, \\
\$ \text { thousand }\end{array}$} \\
\hline $\begin{array}{c}\text { 'Top-World Import' } \\
2019\end{array}$ & Russian Name & & & & \\
\hline Crude oil & Нефть & 1056.0 & & Mineral products & \\
\hline Petroleum gases & Нефтяные газы & 314.8 & & (including oil) & 57500 \\
\hline Cars & Легковые автомобили & 774.3 & \multirow{5}{*}{$\longleftrightarrow$} & \multirow{5}{*}{ Transport } & \multirow{5}{*}{1300} \\
\hline Turbo-jets & Турбореактивные самолеты & 184.8 & & & \\
\hline Trucks & Грузовики & 145.4 & & & \\
\hline Aircraft, spacecraft & $\begin{array}{l}\text { Самолеты, } \\
\text { аппараты }\end{array}$ & 137.5 & & & \\
\hline $\begin{array}{l}\text { Automobile } \\
\text { parts/accessories }\end{array}$ & $\begin{array}{l}\text { Автомобильные запчасти и } \\
\text { аксессуары }\end{array}$ & 400.1 & & & \\
\hline $\begin{array}{l}\text { Medication mixes in } \\
\text { dosage }\end{array}$ & Дозировка смесей лекарств & 405.9 & & $\begin{array}{l}\text { Chemical industry } \\
\text { products }\end{array}$ & 10100 \\
\hline $\begin{array}{ll}\text { Iron } & \text { ores, } \\
\text { concentrates } & \\
\end{array}$ & $\begin{array}{l}\text { Железные } \\
\text { концентраты }\end{array}$ & 144.5 & & $\begin{array}{l}\text { Metals and their } \\
\text { products }\end{array}$ & 682000 \\
\hline $\begin{array}{l}\text { Coal, solid fuels } \\
\text { made from coal }\end{array}$ & $\begin{array}{l}\text { Уголь, твердое топливо из } \\
\text { угля }\end{array}$ & 132.0 & $\leftarrow$ & $\begin{array}{l}\text { Wood and wood } \\
\text { products }\end{array}$ & 92400 \\
\hline
\end{tabular}

Source: Compiled by the authors

It is proposed to estimate the potential share of the region's export commodity position in the total volume of world imports of products on the basis of two coefficients:

1) SPR (Substantial PRoduct), shows the share of the region's exports in meeting the global demand (import) of specific goods and product groups; this ratio can be considered as an indicator reflecting the ability of product groups to control market positions through superiority over competitors;

2) RCA (Revealed Comparative Advantage) or the Ballasa Index [27-30], shows the level of the predicted comparative advantage of the country in the release of a new high-tech type of product; the level is estimated on the basis of the ratio of the planned share of exports of a certain product in the total exports of the country to the share of world exports of similar goods in all world exports [20].

If the level exceeds a unit (the export of a new product will be able to occupy a larger share in the country's exports compared to the share of similar products in world exports), then it is assumed that the country's economy in trade in this product has revealed comparative advantages, which are manifested in relatively low costs for production [27-29].

Revealed comparative advantage can be seen as a rationale for the ability to provide control over market positions assessed on the basis of the RCA coefficient. Thus, both coefficients help to assess and justify the market opportunities of a new high- tech export commodity group in world markets.

At the fourth stage of the methodology, the risks of producers of export products of the region in the markets of importing countries are assessed. For this purpose, we will introduce the concept of critical demand for exports as part of the external effective demand for export products of the region, which, being satisfied in the retrospective period, has high risks associated with the impossibility of meeting it in the future. In the context of this study, the reason for the emergence of critical demand for exports is economic sanctions against the Russian Federation, announced by a number of importing countries (EU, USA, UK, Australia, etc.). The refinement makes it possible to estimate the value of the critical demand for exports on the basis of the calculation of the specific share in export volumes by groups and types of marketable products from countries that have announced economic sanctions to Russia [9, 10].

To determine the shares and volumes of critical supplies for each studied group of commercial products for the studied period of time (2015-2020), the average volume of supplies to importing countries that have announced economic sanctions to Russia is determined. The algorithm of the methodology for the formation of the export growth potential of the regional economy is presented in Figure 2.

Thus, the presented methodology is based on two directions of development of the export potential of the region:

- the first direction is the use of priority types of existing export products as a basis for the 
export potential, characterized by significant specific shares in the volume of regional exports, stable effective demand, corresponding to the stages of growth and / or maturity in world markets;

- the second direction is the inclusion of new promising types of high-tech products from the top positions of world exports (new technologies of materials, new production technologies) that are competitive on world commodity and service markets in the export portfolio of the region.

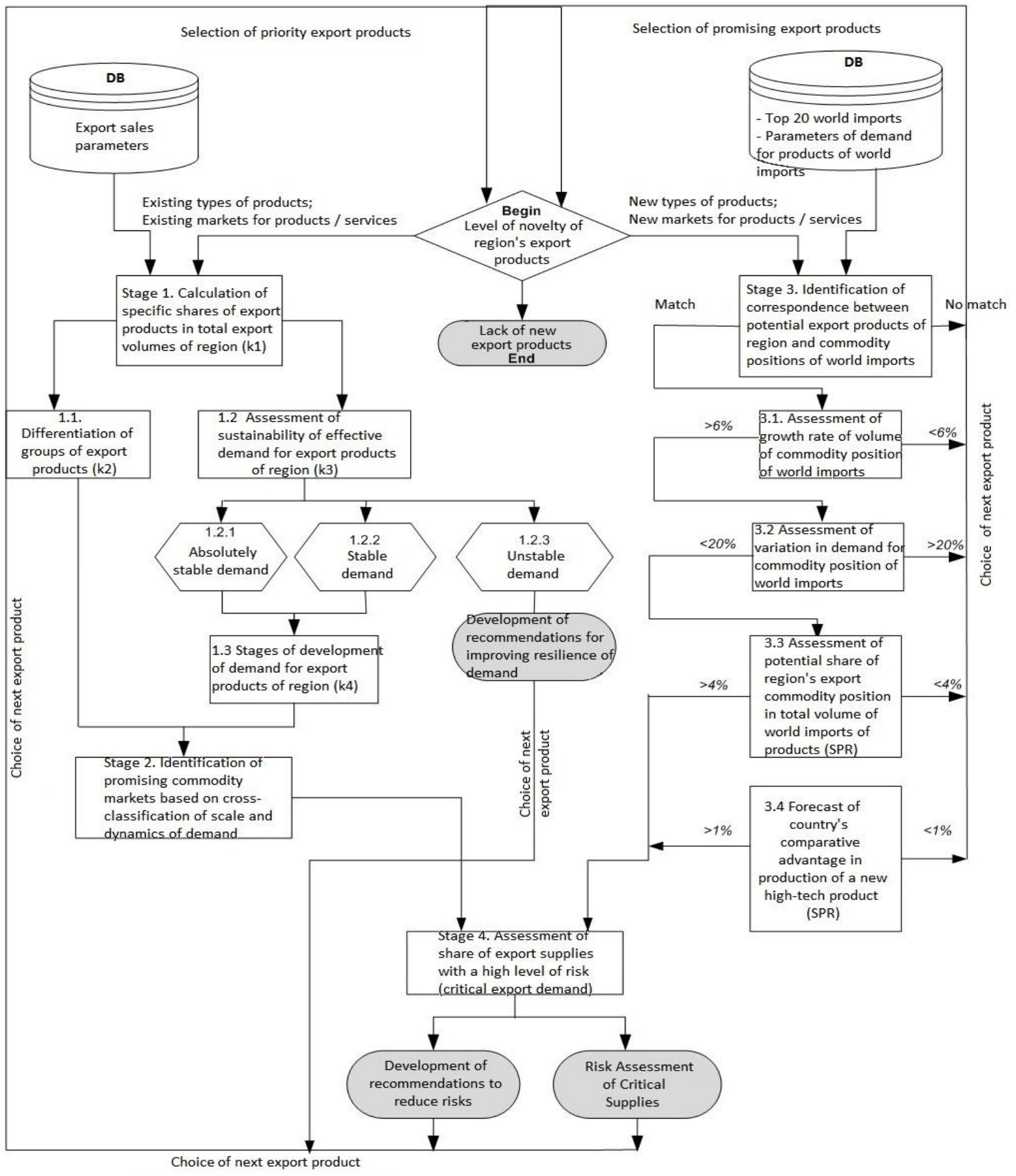

Figure 2. Algorithm for selection of promising and priority types of products for formation of export potential of the region

Source: Compiled by the authors 
Approbation of the proposed methodology on the example of the export of the Krasnoyarsk Territory in the period 2015-2020 allowed obtaining the following results.

1) Analysis of the commodity structure of exports by main types of products for 2015-2020 on the basis of group differences, taking into account the standard deviation, made it possible to substantiate the presence of four levels of the scale of effective demand for export products. The group highest priority for export expansion includes metals, precious stones and items made from them (the average share in the export volumes for the analyzed period was $69.4 \%$ ). The group second priority for export expansion includes two subgroups of products: machinery, equipment and vehicles (2.5\%); food products and agricultural raw materials $(1.0 \%)$. The group lowest priority for export expansion includes six subgroups of export products, among them there are wood products, pulp and paper items (11.7\%), mineral products $(8.6 \%)$, products of chemical industry, rubber $(7.2 \%)$, fuel and energy products $(1.2 \%)$, etc.

2) Stable effective demand studies based on the $\mathrm{XYZ}$-analysis made it possible to reveal differently directed and highly differentiated dynamic changes in annual rates of the effective demand for certain groups of export products in the Krasnoyarsky Territory. Unstable demand is characteristic of the group which includes mineral products, chemical industry products, rubber, wood, pulp and paper items, metals, precious stones and items from them, machinery, equipment and vehicles. Stable demand is characteristic of the group of export fuel and energy products. Absolutely stable demand is typical for such export groups as agricultural products and raw materials, textiles, textile items, footwear, etc.

3) The results of the analysis of stability allow us to substantiate the diagnostics of the current stage of the demand life cycle on the basis of comparison of its trends in the short-term (last 3 years) and middleterm (5 years) periods of development, excluding geopolitical influences associated with economic sanctions against the Russian Federation. We highlighted the following stages of the life cycle of demand for the groups of export products of the Krasnoyarsk Territory:

- the demand for food products and agricultural raw materials, wood products, pulp and paper products, textiles and footwear, machinery, equipment and vehicles is growing;

- the demand for mineral products, fuel and energy products, chemical industry products, rubber is in decline;

- the demand for metals, precious stones and products from them and other types of products is at the stage of the resumption of growth.

4) The results of the positioning of the groups of export products for the matrix 'the level of the scale of effective demand - the level of dynamics of effective demand' (Figure 3) made it possible to form a list of groups of priority products for the formation of the export potential of the region [10].

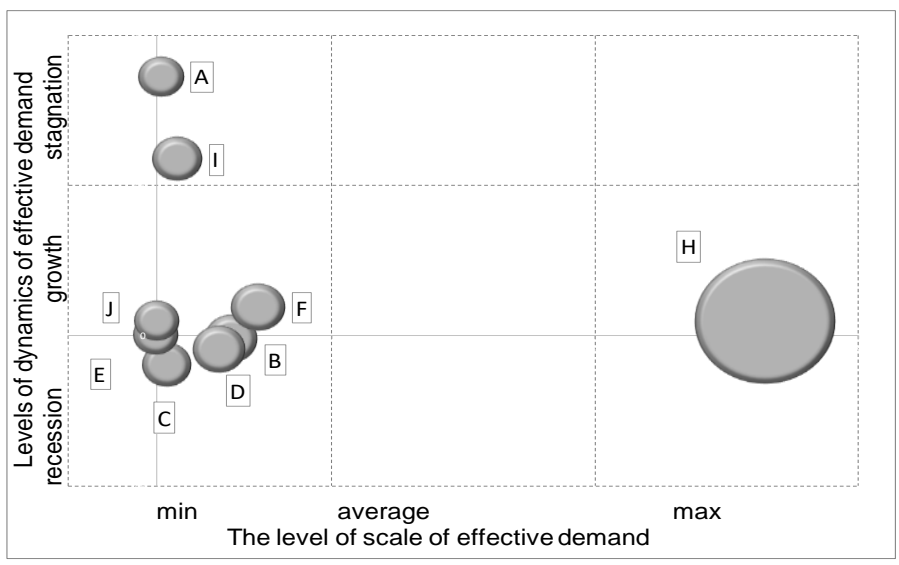

Used designations of commodity groups:

$\mathrm{A}$ - food products and agricultural raw materials

$\mathrm{B}-$ mineral products

$\mathrm{C}$ - fuel and energy products
D - chemical products

E - raw hides, furs

$\mathrm{F}$ - wood, pulp and paper products
$\mathrm{H}$ - metals, precious stones and products from them

I - machinery, equipment and vehicles

$\mathrm{J}$ - other products

Figure 3. Positioning matrix of the region's priority export products

Source: Compiled by the authors 
5) Comparison of the commodity positions of the TOP-20 export of the region and the 'Top of the World Export' in 2019 made it possible to identify six promising export-oriented commodity groups of the region, including (Table 1):

- metals and metal products (iron ores, concentrates);

- mineral products (petroleum, refined petroleum oils, petroleum gases);

- chemical industry products (dosage of drug mixtures);

- machines, equipment and apparatus (car parts and accessories, electro-medical equipment, components and accessories for computers).

6) The assessment of the prospects of products was clarified from the standpoint of risks associated with the difficulty of Russian export supplies to countries that announced economic sanctions. Based on retrospective data, the calculation of the specific share of exports by importing countries was carried out, the volumes of critical supplies in each group of commercial products were determined (Figure 4) [9, 10].

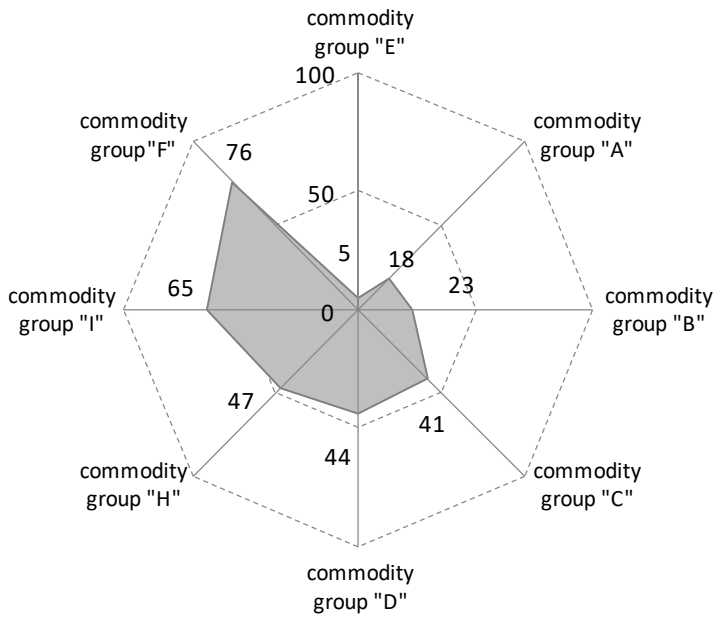

Figure 4. Specific shares of critical export supplies by commodity groups of the Krasnoyarsk Territory for 2018-2020

Source: Compiled by the authors

The results of the positioning of the groups of export products in the matrix 'scale level - the level of dynamics of effective demand' reflecting the relative size of critical export supplies made it possible to determine the commodity boundaries and the size of markets promising for the region's foreign economic activity, as well as to highlight the necessary conditions for the development of markets (maximum localization of production in the region, investment in $\mathrm{R} \& \mathrm{D}$, transfer of innovative technologies, etc.).

\section{DISCUSSION}

The obtained results of the study make it possible to form a list of priority types of high-tech products of regional manufacturers for the formation of the export potential for the growth of the regional economy. Orientation in assessments to meet foreign demand at the expense of existing competitive products of the industrial complex of the region and new types of high-tech products makes it possible to substantiate the priority and prospects of export products from the standpoint of market factors and the possibility of forming new markets. At the same time, the questions of the influence of the production potential and sectoral professional competencies of regional producers on the formation of the export potential of the region remained unsolved in this study.

In this regard, the proposed methodology will obtain further development and the possibility of reaching a new higher level of justification and formation of an evidence base when choosing export products with a high share of added value, provided by the resource potential of regional producers of high-tech sectors. This will increase the efficiency of making managerial decisions (including investment ones) to support regional producers.

\section{CONCLUSION}

So, as a result of the research, we developed the methodology for the formation of export potential of the growth of regional economy. We propose to form a regional export potential on the basis of support for existing priority types of products competitive on the global markets of goods and services as well as on the basis of development of new promising productions of high-tech products that correspond to top positions of world import. In this case, a regional export potential is based, on the one hand, on the scale of market opportunities to expand existing markets and, on the other hand, on the ability of new high-tech products to form new sales markets.

Based on the statistical analysis of the volume dynamics and commodity structure of exports, and taking into account the research of stability of effective demand, we assessed the stage of life cycle of commodity groups and their priority for the region's exports in the short-term and middle-term periods of development. Positioning in the matrix 
'scale level - demand dynamics level' makes it possible to substantiate priorities of export products and determine recommendations for their further production.

Comparison of high-tech export-oriented products of the region with commodity positions of top-world imports gives an opportunity to choose promising types of high-tech products. Subsequent assessment of the potential market share of the region on foreign markets and the level of predicted comparable advantage while releasing a new hightech type of products makes it possible to substantiate a competitive superiority and determine formats for strategic repositioning and cooperation of regional producers. Calculation of volumes of critical export deliveries by product group makes it possible to take into account geopolitical risks in advance and take preventative measures to neutralize their negative impact $[18,31]$.

The proposed methodology allows regional authorities to make a scientifically grounded choice of priority and promising export products, to identify areas of scientific and production cooperation of industrial enterprises and to form institutional conditions for enhancing export activities in regional economy [32-34].

It should be noted that in this approach, priority and prospects of export products are studied exclusively from the standpoint of external effective demand.

However, the methodology does not include assessments of the equilibrium of external demand for high-tech products and products with a high share of added value with the capabilities of regional producers.

\section{AUTHORS' CONTRIBUTIONS}

All authors of the article took an active part in the development of a methodology for the formation of a regional export potential.

Zoya A. Vasilyeva substantiated the scientific research problem, conducted a content analysis and a comparative analysis of scientific approaches to assessing the export potential of the region. Irina V. Filimonenko substantiated the choice of assessment methods, parameters and criteria for product selection, developed an algorithm for the formation of the export potential of the region. Tatiana $\mathrm{P}$. Likhacheva carried out a statistical analysis of the dynamics of volumes and commodity structure of exports on the basis of data from customs statistics.

\section{ACKNOWLEDGMENTS}

The study was carried out within the framework of the project 'Research of Potential of New Materials Technologies, Production Technologies of New Types of High-tech Products and Mechanisms of Cooperation of Regional Manufacturers for Implementation of Priority Investment Projects and Strategic Repositioning on World Commodity Markets" (application code No. 2021020107139) with the support of the Krasnoyarsk Regional Science Foundation.

\section{REFERENCES}

[1] A.N. Spartak, A.Yu. Knobel, T.A. Flegontova, "Prospects for increasing Russian non-resource exports" [Perspektivy narashchivaniya rossiyskogo nesyr'yevogo eksporta], M.: TsSR Ekonomicheskoye razvitiye, 2018, 132 p. (In Russ.).

[2] S.G. Kamolov, "Export orientation of the wind farm" [Ob eksportnoy orientatsii VES], BIKI, 1997, vol. 139, pp. 2-3. (In Russ.).

[3] R.M. Prytkov, G.I. Nemirova, "Formation and development region export potential", Vestnik of the Orenburg State University, 2011, vol. 13(132), pp. 387-393. (In Russ.).

[4] M.E. Seyfullaeva, "Mechanism for formation of export potential of region" [Mekhanizm formirovaniya eksportnogo potentsiala regiona], Region, 2007, vol. 1, pp. 68-83. (In Russ.).

[5] N.V. Vorobieva, "Development and evaluation of export potential of agrarian region (on the example of Stavropol Territory)", Agricultural Bulletin of Stavropol Region, 2012, vol. 3(7), pp. 66-69. (In Russ.).

[6] O.R. Nadirov, M.A. Ubaydullaev, Ju.P. Alekseeva, "Export potential of the territory: essence and current state", Economy and Society, 2019, vol. 7-8(12), pp. 15-23. (In Russ.).

[7] A. Abdimomynova, "Development factors of export potential of the region: Capabilities in minerals and infrastructure sector", Academy of Strategic Management Journal, 2018, vol. 17(3), pp. 1-11.

[8] "Regions of Russia. Socio-economic indicators. 2020: R32 Statistic collection", M.: Rosstat, 2020, 1242 p. (In Russ.).

[9] "Krasnoyarsk Territory in Figures 2019: 
Statistic collection”, Krasnoyarsk: Krasnoyarskstat, 2020, vol. 1.37.4, 159 p. (In Russ.).

[10] "Customs statistics of foreign trade. FCS (Federal Customs Service)" [Tamozhennaya statistika vneshney torgovli. FTS], 2021. (In Russ.). Retrieved from http://www.customs.ru/index.php?option=com content $\&$ view $=$ article $\&$ id $=13858 \&$ Itemid $=2095$

[11]N. Hammar, Y. Belarbi, "R\&D, innovation and productivity relationships: Evidence from threshold panel model", International Journal of Innovation Studies, 2021, vol. 5(3), pp. 113126. DOI: $10.1016 /$ j.ijis.2021.06.002

[12]I.V. Filimonenko, "The local markets' role and position in stable development of the region", Modern Problems of Science and Education, 2014, vol. 3, p. 420. (In Russ.).

[13]L.V. Larchenko, "Restructuring of the economy of resource-extracting regions of the Russian North and the Arctic as a necessary condition for sustainable territorial development", IOP Conference Series: Earth and Environmental Science, 2021, vol. 678(1), p. 012018. DOI: 10.1088/1755-1315/678/1/012018

[14]I.V. Filimonenko, Z.A. Vasilyeva, T.P. Likhacheva, "Method for identification of the regional economy's needs in import substitution products", Russian Journal of Entrepreneurship, 2015, vol. 16(21), pp. 36593674. (In Russ.). DOI: 10.18334/rp.16.21.2071

[15]F. Mammadova, M. Mammadov, A. Kariuk, E. Mammadov, "Economic Reforms and Development Strategies as Providing Sustainable Development", Lecture Notes in Civil Engineering, 2021, vol. 181, pp. 669-676. DOI: 10.1007/978-3-030-85043-2_63

[16] "World's Top Export Products", 2021. Retrieved from https://www.worldstopexports.com/worlds-topimports-products-countrie/

[17]C.K. Dinh, Q.T. Ngo, T.T. Nguyen, "Mediumand high-tech export and renewable energy consumption: Non-linear evidence from the ASEAN countries", Energies, 2021, vol. 14(15), p. 4419 . DOI: $10.3390 /$ en 14154419

[18]O.P. Zvyagintseva, I.N. Mayatskaya, E.E. Matveeva, "High-Tech Industrial Complex: Safety and Quality of Development", IOP Conference Series: Earth and Environmental
Science, 2021, vol. 666(6), p. 062049. DOI: $10.1088 / 1755-1315 / 666 / 6 / 062049$

[19]A. Borodin, M. Tvaronavičienè, I. Vygodchikova, G. Panaedova, A. Kulikov, "Optimization of the structure of the investment portfolio of high-tech companies based on the minimax criterion", Energies, 2021, vol. 14(15), p. 4647 . DOI: $10.3390 /$ en 14154647

[20] J. Wang, Z. Ziqi, H. Wang, "Research on Influencing Factors of Export Complexity of Chinese High-tech Industry Based on Big Data Analysis", E3S Web of Conferences, 2021, vol. 235, p. $03013 . \quad$ DOI: $10.1051 / \mathrm{e} 3$ sconf $/ 202123503013$

[21] "Foundations of the National Technology Initiative" [Osnovy Natsional'noy tekhnologicheskoy initsiativy], 2015. (In Russ.). Retrieved from http://www.labrate.ru/20151229/20150403_osn ova_nti_version-ras.pdf

[22] S. Rastvortseva, A. Amanalieva, "The concept of technological proximity in the development of European Union national innovative systems", Bulletin of Geography. SocioEconomic Series, 2021, vol. 51(51), pp. 35-45. DOI: $10.2478 /$ bog-2021-0003

[23] V.I. Byvshev, K.V. Parfent'eva, D.I. Uskov, I.A. Panteleeva, "Regional Institutions to Support Science and Innovation: Mechanisms to Improve the Efficiency of Their Operation", Journal of Siberian Federal University. Humanities and Social Sciences, 2021, vol. 15(4), pp. 559-579. DOI: 10.17516/19971370-0706

[24]Yu.S. Otmakhova, N.I. Usenko, D.A. Devyatkin, V. Songkassiri, "Assessing export potential of the country in the context of global demand in the world food market", Economic and Social Changes: Facts, Trends, Forecast, 2019, vol. 12(4), pp. 104-122. (In Russ.). DOI: 10.15838/esc.2019.4.64.7

[25]E.Yu. Shirokova, "Influence of sanctions on foreign trade of Russia", Scientific Bulletin of the Southern Institute of Management, 2019, vol. 1(25), pp. 87-94. (In Russ.). DOI: 10.31775/2305-3100-2019-1-87-94

[26] S.A. Belyaev, "The change in the trade relations between Russia and the countries of the European Union amid economic sanctions", Azimuth of Scientific Research: Economics and Administration, 2019, vol. 8(1-26), pp. 86-88. 
(In Russ.). DOI: 10.26140/anie-2019-0801-0017

[27]Z. Chen, J. Gang, Z. Qian, "Stock returns and carry trades", The North American Journal of Economics and Finance, 2021, vol. 58, p. 101507. DOI: 10.1016/j.najef.2021.101507

[28]B. Balassa, "Trade Liberalization and "Revealed" Comparative Advantage", The Manchester School, 1965, vol. 33, pp. 99-123.

[29] A. Chapcakova, D.R. Kascakova, J. Heckova, S. Kolesarova, "Research of comparative advantages in the context of determinants of cross-border mergers and acquisitions in the European area", Montenegrin Journal of Economics, 2021, vol. 17(4), pp. 181-188.

[30] M.A. Gvozdeva, M.V. Lysyuk, I.L. Lyubimov, "Atlas of economic complexity of Russian regions: Methodological issues" [Atlas ekonomicheskoy slozhnosti rossiyskikh regionov: voprosy metodologii], M.: RANKhiGS, 2016. (In Russ.).
[31]Z. Liu, S. Zhu, "External knowledge environments and new export market expansion of domestic enterprises", Progress in Geography, 2021, vol. 40(2), pp. 194-206. DOI: 10.18306/dlkxjz.2021.02.002

[32]E. Ipsmiller, K.D. Brouthers, D. Dikova, "Which export channels provide real options to SMEs?", Journal of World Business, 2021, vol. 56(6), p. $101245 . \quad$ DOI: 10.1016/j.jwb.2021.101245

[33]B. Kheyfets, V. Chernova, "Comparative assessment of the influence of a technological factor on economic growth", Eastern-European Journal of Enterprise Technologies, 2021, vol. 1(13-109), pp. 6-15. DOI: 10.15587/17294061.2021.225526

[34]X. Yang, M. Luo, "Analysis on the export competitiveness of shenzhen high-tech products”, E3S Web of Conferences, 2020, vol. 214, p. 02048 . DOI: $10.1051 / \mathrm{e} 3$ sconf/202021402048 